\title{
Review of species of the genus Macropsidius Ribaut, 1952 (Homoptera: Cicadellidae: Macropsinae) of Russia and adjacent territories
}

\section{Обзор видов рода Macropsidius Ribaut, 1952 (Homoptera: Cicadellidae: Macropsinae) России и сопредельных территорий}

\author{
D.Yu. Tishechkin \\ A.Ю. Тишечкин
}

Department of Entomology, Faculty of Biology, M.V. Lomonosov Moscow State University, Vorobyevy Gory, Moscow, 119991 Russia. Email: macropsis@yandex.ru

Кафедра энтомологии Биологического факультета Московского государственного университета имени М.В. Ломоносова, Воробьевы Горы, Москва, 119991 Россия.

KEY WORDS: leafhoppers, Homoptera, Auchenorrhyncha, Cicadellidae, Macropsinae, Macropsidius, taxonomy, distribution, Palaearctic, Russia.

КЛЮЧЕВЫЕ СЛОВА: цикадки, Homoptera, Auchenorrhyncha, Cicadellidae, Macropsinae, Macropsidius, систематика, распространение, Палеарктика, Россия.

ABSTRACT. Annotated check list of species of Macropsidius of Russia, Transcaucasia, Kazakhstan, Central Asia, and Mongolia with main diagnostic characters and data on biology and distribution is provided. Illustrated key to species is given. The synonymy of $M$. arenosus Mitjaev, 1971, syn. n. and M. ersinicus Vilbaste, 1980, syn. n. under Macropsidius involutus Dlabola, 1963 is established.

РЕЗЮМЕ. Приведён список видов Macropsidius фауны России, Закавказья, Средней Азии, Казахстана и Монголии с указанием основных диагностических признаков и данными по распространению и биологии, а также иллюстрированный ключ для их определения. Установлена синонимия Macropsidius involutus Dlabola, $1963=$ M. arenosus Mitjaev, 1971, syn. n. $=$ M. ersinicus Vilbaste, 1980, syn. n.

The genus Macropsidius Ribaut, 1952 (Homoptera: Auchenorrhyncha: Cicadellidae: Macropsinae) was described as monotypic for M. dispar (Fieber, 1868) [Ribaut, 1952]. However, even eleven years later Dlabola [1963] included in this genus 11 species, 6 of which were described as new. In the subsequent years the review of Macropsidius of Caucasus and Transcaucasia [Logvinenko, 1981], and a series of works by Mityaev [1967, 1971, 1973, 1990] with descriptions of 11 species from Kazakhstan were published along with separate original descriptions by other authors [Emelyanov, 1964, 1972; Vilbaste, 1965, 1980; Lukyanova, 1992]. As a result, at the end of XX century the genus included about 40 Palaearctic species, considerable part of which being known only from single of several localities situated close to each other. These facts were in contradiction with ecological data, since almost all Macropsidius species feed on wormwood (Artemisia spp., Asteraceae) and inhabit arid plains and midlands of Asiatic part of Palaearctic, so there is nothing to prevent their wide distribution.

In the course of our investigations it has been found that a number of Macropsidius species have much wider ranges than it was expected and several ones were described under different names from different regions [Tishechkin, 2006, 2007, 2011]. In total, eight synonyms were established in the articles abovementioned; on the other hand, investigation of a great material collected in Kazakhstan and Central Asia revealed only two new species. Consequently, there is good reason to believe, that the most part of species in this genus are already described. Moreover, several forms from Mediterranean and West China apparently are synonyms. Therefore, the number of species in this genus will hardly increase in future.

The present article includes an annotated check list of species of Macropsidius of Russia, Transcaucasia, Kazakhstan, Central Asia, and Mongolia with main diagnostic characters, data on host plants and distribution, and illustrated key to species.

Type specimens of species described by J. Dlabola are deposited in Muséum National d'Histoire Naturelle, Paris and National Museum, Prague. The rest of the material investigated is deposited in the collections of Zoological Institute of the Russian Academy of Sciences (St.-Petersburg) and Zoological Museum of M.V. Lomonosov Moscow State University.

The genus Macropsidius is closely related to Macropsis Lewis, 1836 and distinctly differs from the latter only by shorter (sometimes considerably reduced) py- 
gofer processes far not reaching its upper margin. In addition, representatives of Macropsidius for the most part are smaller and more stout than Macropsis, with vertex in dorsal aspect of almost the same width in the middle and near eyes (narrowed in the middle in Macropsis). In external appearance almost all representatives of the genus are similar (Figs 1-6, 20-28) and as a rule are easily distinguishable from Macropsis and Hephathus Ribaut, 1952.

Typically, head, pronotum and mesonotum are yellowish or pale brownish with distinctive black pattern, in males darker than in females (Figs 1-9). Black pattern on face includes vertical spot at the apex of crown, two round spots at its each side, ocellar spots, two longitudinal and somewhat curved outwards large spots in the middle part of face and one or several small spots on frontoclypeus (Fig. 7). Pronotum with one spot in the middle of the fore margin and two spots next to eyes (Figs 1-6). At the distal ends of the latters several small partially merged spots usually present. Mesonotum pattern is typical for Macropsinae and includes longitudinal median spot in the fore half, a pair of small round spots in central part both sides of midline, and large triangular spots in side angles (Fig. 1). Black pigmentation can vary greatly within a species. For this reason in certain specimens some spots are hardly distinguishable or absent, whereas in other ones they are merged and form black pattern of complex shape (Figs 7-9, 20-23).

Forewings transparent or infumose, claval suture, apex, and most part of cells usually more or less darkened. Veins light, the main ones sometimes are milkywhite, especially at the wing base.

Hereinafter such coloration is referred to as typical.

In the revision of the generic classification of the world Macropsini Hamilton [1980] treated Macropsidius as a subgenus of Macropsis and included in it three North American species with shortened pygofer processes. Formally, they can be included into Macropsidius based on this character. On the other hand, American species differ from Palaearctic ones in larger size, more slender body, and another coloration. In addition, they feed on Rosaceae (Prunus), i.e. have quite a different ecological preferences [Hamilton, 1983]. For these reasons here we treat Macropsidius as a separate genus including only Palaearctic species.

Representatives of Macropsidius are most diverse in the steppes and deserts of Central Asia. Considerable number of species occurs also in Transcaucasia and Mediterranean. Only two species are distributed far outside the Palaearctic arid zone. These are M. sahlbergi (Flor, 1861) widespread in Central Europe and $M$. niger (Matsumura, 1915) occurring from the steppes of South Siberia and Mongolia eastwards as far as the Russian Maritime Territory (Pacific Coast).

The genus under consideration is most uniform in host preferences. Almost all known species feed on wormwood (Artemisia spp.). The only exception is M. maculatus Mitjaev, 1971 dwelling both on Artemisia karatavica Krasch. et Abol. ex. Poljak. and on Lepidolofa spp. (also Asteraceae). Only few species are monofagous; most ones can feed on several wormwood species belonging to different sections or even subgenera.

Male vibrational calling signals in Macropsidius are single or repeated phrases with complex temporal pattern [Tishechkin, 2003, 2006, 2007, 2011]. Immediately before copulation a male produces copulatory signals differing from the calling ones [Tishechkin, 2003].

Pygofer processes in Macropsidius quite often vary both in length and in the shape having acute or, by contrast, widely rounded tips (Figs 10-14). Occasionally, left and right processes differ in shape even in the same individual. The shape of styles does not provide diagnostic characters because the expansion in their distal part varies greatly within a species (Figs 15-19). Moreover, in certain species individuals with expanded or with narrow styles are more abundant and this makes situation even more difficult.

For this reason species diagnostics in Macropsidius is based almost exclusively on penis shape. However, in many species penis possess longitudinal lateral and/or ventral laminate carinae so much variable in shape and size, that occasionally new species were described based on males with extreme variants of their structure. Therefore, sometimes dissection of several males is necessary for reliable species identification.

Annotated check list of Macropsidius species of Russia and adjacent territories

\section{Macropsidius duuschulus \\ Dlabola, $15^{\text {th }}$ October 1965 \\ Figs 1-3, 15-17, 34-39}

Macropsidius albinervis Vilbaste, December 1965 [Tishechkin, 2007]

Macropsidius rigidus Mitjaev, 1971 [Tishechkin, 2007]

Coloration typical (Figs 1-3). Penis rather narrow, without longitudinal carinae, with two apical processes somewhat variable in shape and size (Figs 34-39). In the shape of penis distinctly differs from all other representatives of the genus with the exception of closely related $M$. arenicola Em.

Illustrated redescription with data on acoustic signals is given in Tishechkin [2007]. Identification of $M$. duuschulus is based on original description, identification of M. albinervis - on investigation of the specimens from Altai Mts. from whence this form was described. Identification of $M$. rigidus is based on investigation of specimens from Kazakhstan identified by Prof. I.D. Mityaev.

DISTRIBUTION. South-Eastern Kazakhstan (Dzhungarskiy Alatau, Tarbagatay, and Saur Mtn. Ranges), Altai Mts., steppes of South Siberia (Tyva, South-Eastern Transbaikalia), Mongolia, apparently also adjacent regions of Northern China.

HOST. Artemisia laciniata Willd.

Рис. 1-33. Цикадки рода Macropsidius: 1-3 - M. duuschulus, вид тела сверху; 4-6 - то же, M. valiturus; 7-9 — M. vallaris, лицо; 1012 - M. involutus, отросток доли пигофора; 13-14 - то же, M. compactus; 15-17-M. duuschulus, cтилус; 18-19 - то же, M. kopetdagicus; 20-23 - M. arenicola, вид тела сверху; 24-26 - то же, M. vallaris; 27-28 - то же, M. kopetdagicus; 29-33 - то же, M. niger. 

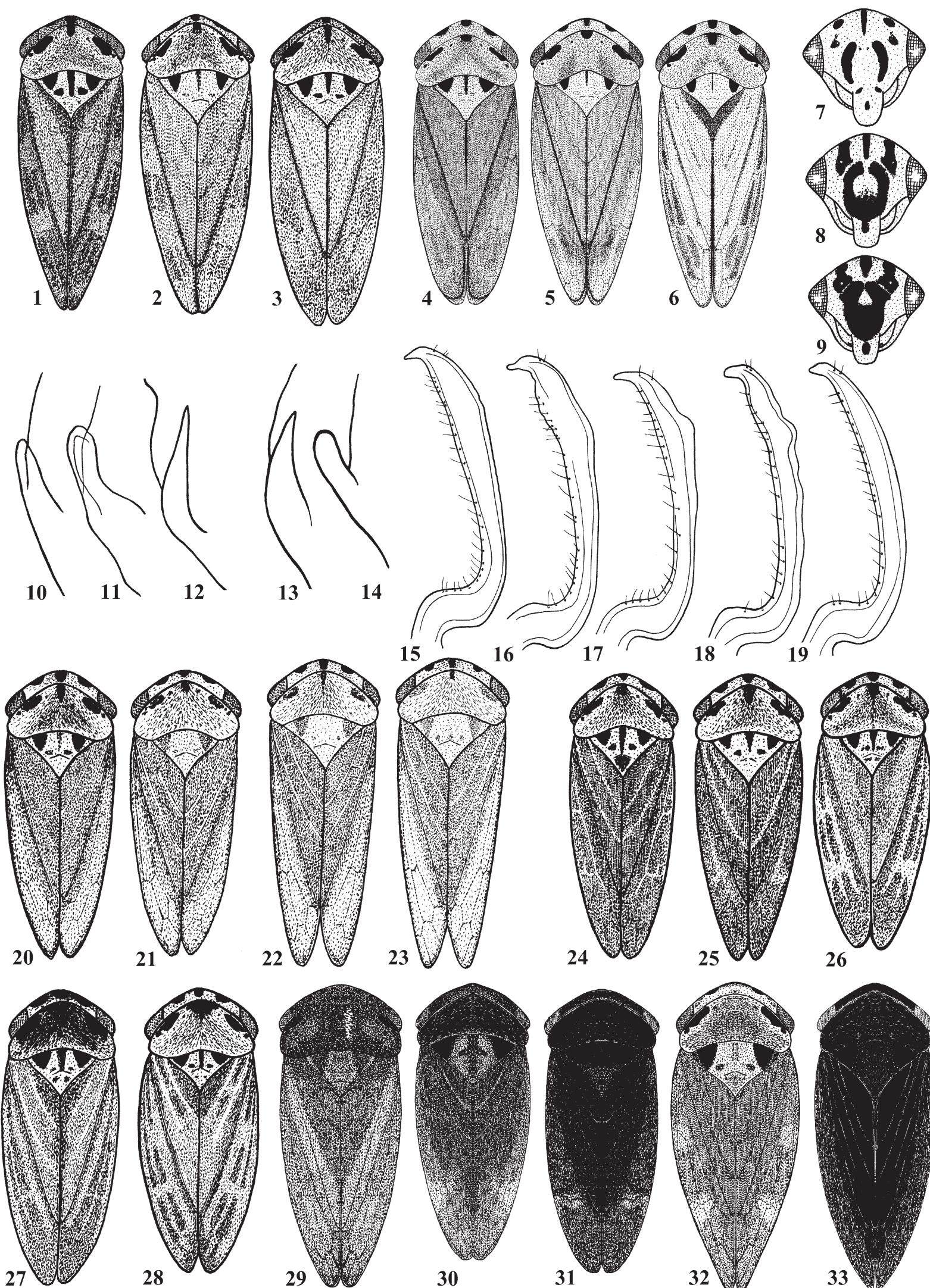

Figs 1-33. Leafhoppers of the genus Macropsidius: 1-3 - M duuschulus, dorsal view; 4-6 - same, $M$ valiturus; 7-9 - M. vallaris, face; 10-12 - M. involutus, pygofer processes; 13-14 - same, M. compactus; 15-17-M. duuschulus, styles; 18-19 - same, M. kopetdagicus; 20-23 - M. arenicola, dorsal view; 24-26 - same, M. vallaris; 27-28 - same, M. kopetdagicus; 29-33 - same, M. niger. 


\section{Macropsidius arenicola Emeljanov, 1972} Figs 20-23, 40-43

Coloration typical (Figs 20-23). Similar to M. duuschulus, but differs from it in larger apical part of penis (Figs 40 41) and wider penis shaft in lateral view (Figs 42-43), smaller size (body length in male $3.1-3.5 \mathrm{~mm}$, in female $3.4-4.1 \mathrm{~mm}$; in M. duuschulus $3.5-4.1$ and $3.8-4.5 \mathrm{~mm}$, respectively), and lighter coloration. Two large series of specimens from Mongolia vere investigated in addition to single ones. All diagnostic characters remain constant within a series of specimens collected at the same locality and date. For this reason we treat this form as a separate species, though very similar to $M$. duuschulus.

Investigation of many specimens from Mongolia showed that the number of subapical teeth on 2nd valvulae of ovipositor in M. arenicola and M. duuschulus, contrary to data in Tishechkin [2007], considerably overlaps.

Illustrated redescription is given in Tishechkin [2007], identification of species is based on investigation of specimens from Mongolia identified by Prof. A.F. Emelyanov.

DISTRIBUTION. Extreme South-East of Kazakhstan, Saur Mtn. Range [Mityaev, 2002], Mongolia [Emelyanov, 1972].

HOST. In Mongolia was collected from Artemisia gr. arenaria [Emelyanov, 1972].

\section{Macropsidius abrotani Emeljanov, 1964} Figs 44-46

Coloration typical. Penis without longitudinal carinae, with two sometimes almost reduced apical denticles (Figs 44-46). Distinctly differs from other species by penis shape.

This species was described in brief terms in the key to species of leafhoppers of European Russia [Emelyanov, 1964]. Detailed redescription with data on acoustic signals is provided in Tishechkin [2006]. Identification of species is based on original description and investigation of specimens from many localities in Russia and Kazakhstan.

DISTRIBUTION. Southern Ukraine, Central and Southern European Russia (northwards at least as far as the Oka River Valley), Kazakhstan with the exception of southern deserts and mountain regions. Record from Kyrgyzstan [Issyk-Kul' Depression; Abdurakhimov, 1972] needs verification and possibly refers to M. majusculus Mitjaev, 1971.

HOST. Artemisia abrotanum L. $(=$ A. procera Willd. $=$ A. proceraeformis Krasch.).

\section{Macropsidius ilandagicus Logvinenko, 1981 Figs 47-48}

Coloration typical. Differs from all other species by peculiar shape of penis having basal expansion densely covered with minute denticles (Figs 47-48).

Identification of species is based on original description [Logvinenko, 1981].

DISTRIBUTION. Transcaucasia (Nakhichevan').

HOST. Artemisia sp. [Logvinenko, 1981].

\section{Macropsidius kalbensis Mitjaev, 1971 Figs 49-50}

Coloration typical. Differs from all other representatives of the genus with the exception of $M$. sahlbergi (Flor, 1861) by penis bearing very wide ventral carina (Figs 49-50).

Identification of species is based on investigation of paratypes and specimens from Eastern Kazakhstan identified by Prof. I.D. Mityaev.

DISTRIBUTION. Was described from the steppes at the foothills of Kalbinskiy Mtn. Range, Kazakh part of Altai Mts.
[Mityaev, 1971, 1973]. Later was found in the materials from Eastern Mongolia (Eastern and Sukhe-Bator Aimags). Apparently inhabits steppes of Central Asia from Eastern Kazakhstan to Eastern Mongolia.

HOST. Was collected from Artemisia sericea Web. ex Stechm., A. frigida Willd. (subgenus Artemisia, section Absinthium), and A. compacta Fisch. ex DC. (subgenus Seriphidium).

\section{Macropsidius sahlbergi (Flor, 1861)}

$$
\text { Figs 51-57 }
$$

Pediopsis sahlbergi Flor, 1861

Coloration typical. As in M. kalbensis, penis with very wide ventral carina (Figs 51-57). Differs from $M$. kalbensis by shorter apical part and more narrow shaft of penis in ventral view (Fig. 51).

Illustrated redescription of $M$. sahlbergi with data on acoustic signals is given in Tishechkin [2006], identification of species is based on Dlabola [1963] and investigation of specimens from many localities in European Russia.

DISTRIBUTION. Eastern Europe northwards as far as the Baltic Region, Ukraine, Central and Southern European Russia, Southern part of West Siberia, plains of Kazakhstan. Also was found in two localities in Kyrgyzstan, both in West Tien Shan Mts.: mountain steppes $20 \mathrm{~km}$ North of TashKumyr and Karasuu River Gorge $10 \mathrm{~km}$ upstream from Karakul' Town (Figs 55-57).

HOST. Artemisia campestris L. and A. arenaria DC. (both from the subgenus Dracunculus).

\section{Macropsidius majusculus Mitjaev, 1971 Figs 58-63}

Coloration typical. Penis with narrow, sometimes enirely reduced lateral carinae in the middle of the shaft (Figs 58, 62). Occasionally, carinae are visible only as viewed from the apex in a somewhat lateral view (Fig. 61). Carinae are bent dorsally so that in lateral view sometimes produce an illusion of a single carina on dorsal side of a shaft (Figs 59-60). Apex with one or two denticles on each side of the gonopore.

Identification of species is based on original description and investigation of specimens from Southern Kazakhstan identified by Prof. I.D. Mityaev.

DISTRIBUTION. Southern Kazakhstan (Zailiyskiy Alatau Mtn. Range), Kyrgyzstan (Kungey and Terskey Alatau Mtn. Ranges, Kekemeren River Valley).

HOST. Was collected from wormwoods from Abrotanum section: A. laciniata [Mityaev, 2002] and A. santolinifolia Turcz. ex Bess. (our data).

\section{Macropsidius kopetdagicus Tishetshkin, 2007} Figs 18-19, 27-28, 64-67

Coloration typical. In most dark males almost all face and fore part of pronotum black, membrane of forewings infumose, almost black (Figs 27-28). Penis narrow, without longitudinal carinae, with groups of denticles on both sides of the apex (Figs 64-67).

DISTRIBUTION. Was found only in Western KopetDag Mtn. Range (Turkemenistan).

HOST. Artemisia sp.

\section{Macropsidius niger (Matsumura, 1915)}

Figs 29-33, 68-77

Agallia nigra Matsumura, 1915

Hephathus niger Matsumura, 1915

Macropsis baicalica Kusnezov, 1929

Hephathus pygmaeus Vilbaste, 1966

Macropsidius bajanagti Dlabola, 1967 

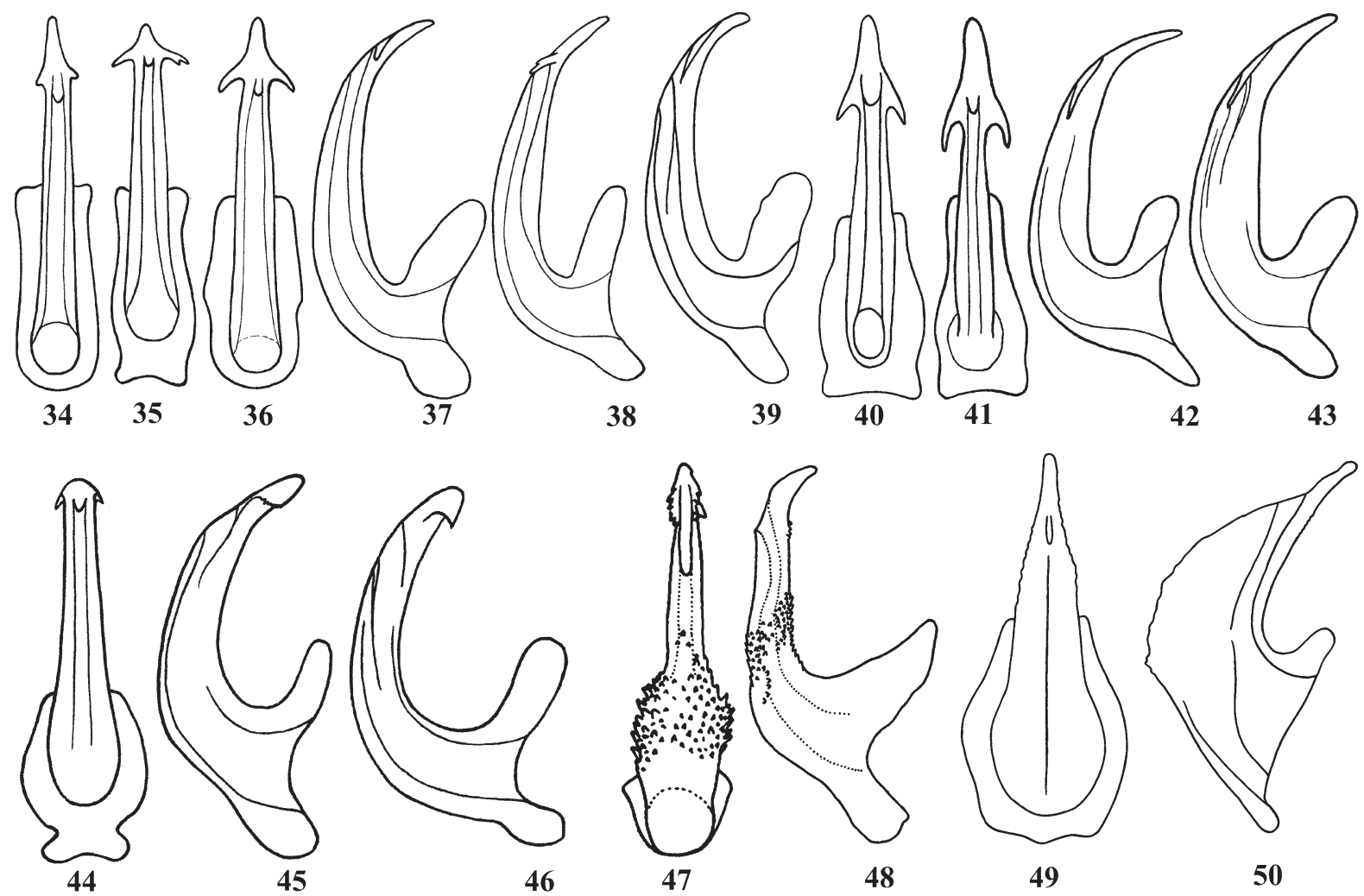

$46 \quad 47$

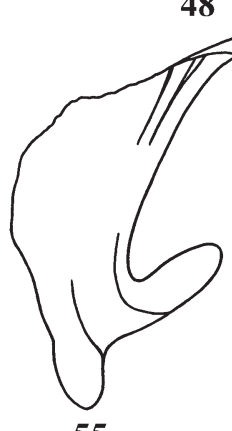

49

50

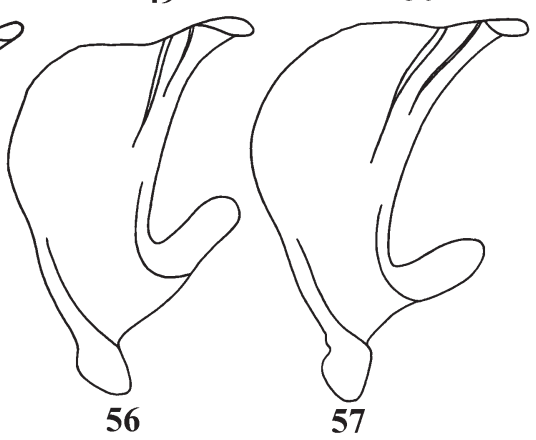

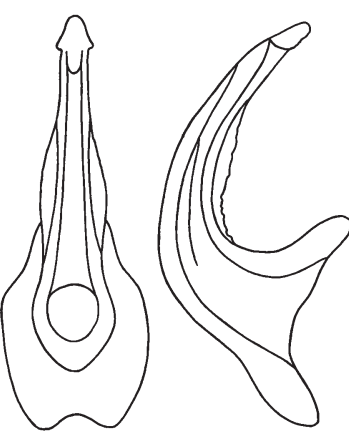

58

59

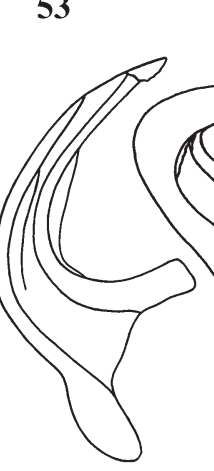

60

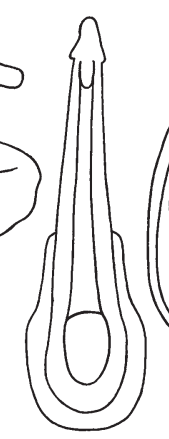

62

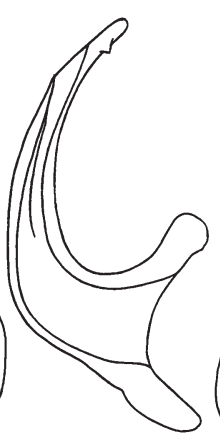

63

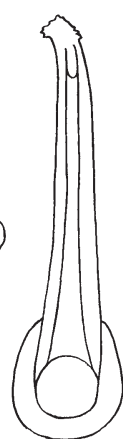

64

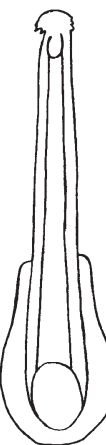

65

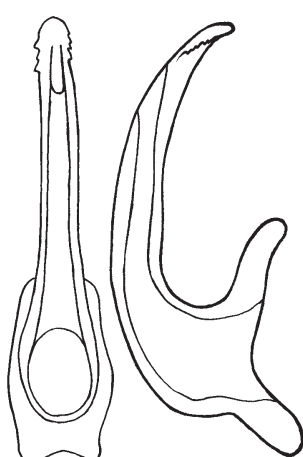

66

Figs 34-67. Leafhoppers of the genus Macropsidius: 34-36, 40-41, 44, 47, 49, 51, 58, 62, and 64-66 - penis, back view; 37-39, 4243, 45-46, 48, 50, 52-57, 59-60, 63, and 67 - same, side view; 61-same, apical and somewhat lateral view. 34-39-M. duuschulus; 4043 - M. arenicola; 44-46-M. abrotani; 47-48-M. ilandagicus (after Logvinenko, 1981); 49-50-M. kalbensis; 51-57-M. sahlbergi (51-54 - males from Moscow Area, 55-57 - males from Kyrgyzstan); 58-63 - M. majusculus (58-61 - males from Kokomeren Riv. Valley, 62-63 - male from Kungey Alatau Mtn. Ridge); 64-67-M. kopetdagicus.

Рис. 34-67. Цикадки рода Macropsidius: 34-36, 40-41, 44, 47, 49, 51, 58, 62, 64-66 - пенис сзади; 37-39, 42-43, 45-46, 48, 50, 52-57, 59-60, 63, 67 - то же, сбоку; 61 - то же, со стороны вершины и несколько сбоку. 34-39-M. duuschulus; 40-43- M. arenicola; 44-46 - M. abrotani; 47-48 - M. ilandagicus (по Логвиненко, 1981); 49-50 - M. kalbensis; 51-57 - M. sahlbergi (5154 — самцы из Московской обл., 55-57 — самцы из Кыргызстана); 58-63 — M. majusculus (58-61 - самцы из долины Кекемерена, 62-63 - самец с Кунгей Алатау); 64-67 - M. kopetdagicus. 
Macropsidius niger bajanagti Dlabola, 1967 [Tishechkin, 2011]

Differs from other representatives of the genus by uniform black or unfumose coloration (Figs 29-33). Only in most lightcoloured specimens black pattern typical for Macropsidius is distinguishable on face, pro- and mesonotum (Fig. 32). Penis with very narrow, occasionally hardly visible lateral carinae usually dentified in apical half (Figs 68-77). Specimens from the steppes of South Siberia and Mongolia have lighter coloration and broader carinae, than the specimens from the Russian Far East (Figs 68-72 and 73-77, respectively). This is good reason to treat the form from the steppes of Central Asia as a separate subspecies, $M$. niger bajanagti.

Identification of species is based on description in Anufriev [1978]. Illustrated redescription with data on acoustic signals and hosts is given in Tishechkin [2011].

DISTRIBUTION. Steppes of South Siberia and Northern Mongolia, Southern part of the Russian Far East, Korea, apparently also adjacent territories of Northern China.

HOST. In South Siberia (Tyva) was collected from Artemisia glauca Pall. ex Willd. (subgenus Dracunculus), in the Russian Far East (Khabarovsk Region and Maritime Territory) lives on species from the section Artemisia.

\section{Macropsidius chazarianus Logvinenko, 1981 Figs 78-83}

Coloration typical, in males forewings very rarely are darkened. Penis in basal part with wide lateral carinae and with groups of denticles on both sides of the gonopore (Figs 78-83).

Identification of species is based on original description and on investigation of specimens from Astrakhan' Area and from Mangyshlak Peninsula (Northern Kazakhstan). Illustrated redescription is given in Tishechkin [2006].

DISTRIBUTION. Sands of the Northern part of Caspian Depression from North Caucasus (environs of Makhachkala, Dagestan) to Mangyshlak.

HOST. Wormwoods from the subgenus Dracunculus: A. arenaria, A. scoparia Waldst. et Kit.

\section{Macropsidius compactus Mitjaev, 1990} Figs 13-14, 84-86

Coloration typical. Penis narrow with small lateral carinae in the basal half and with groups of denticles on both sides of the gonopore (Figs 84-86).

Identification of species is based on investigation of paratypes and specimens from South-Eastern Kazakhstan identified by Prof. I.D. Mityaev. Illustrated redescription with data on acoustic signals is given in Tishechkin [2006].

DISTRIBUTION. Was described from Northern and North-Western slopes of Tarbagatay Mtn. Range (SouthEastern Kazakhstan), later was found in Naursum Nature Reserve (Northern Kazakhstan) and in Transvolga part of Saratov Area. Apparently, the range includes the most part of the territory of Kazakhstan and Transvolga regions of Southern European Russia.

HOST. Wormwood species from all three subgenera (Artemisia, Dracunculus, and Seriphidium).

\section{Macropsidius maculatus Mitjaev, 1971} Figs 87-92

Coloration typical. Penis with wide lateral carinae divergent in basal two thirds of a shaft and convergent in apical part (Figs 87-92). Apex rather short, with a denticle on each side of the gonopore.

Identification of species is based on investigation of paratypes and specimens from Southern Kazakhstan identified by Prof. I.D. Mityaev.

DISTRIBUTION. Common species in Syrdaryinskiy Karatau Mtn. Range (Southern Kazakhstan). Also, was found in Talas Alatau Mtn. Range (Daubaba; Mityaev, 2002) and in the Western part of Chatkal Mtn. Range (Chatkal'skiy Nature Reserve, Uzbekistan; our data).

HOST. Artemisia karatavica Krasch. et Abol. ex. Poljak., Lepidolopha karatavica Pavl. and L. komarovii C. Winkl. (= L. filifolia Pavl.) [Mityaev, 2002]. The only Macropsidius species feeding in addition to wormwood on other Asteraceae.

\section{Macropsidius desertus Mitjaev, 1967} Figs 93-98

Coloration typical. Very similar to M. maculatus and differs from it only by stronger dentified and longer apical part of penis (Figs 93-98).

Identification of species is based on original description and investigation of specimens from Southern Kazakhstan identified by Prof. I.D. Mityaev.

DISTRIBUTION. Southern and South-Eastern Kazakhstan (sand deserts South of the Balkhash Lake; the Zaisan Lake Depression), Uzbekistan, Northern Tajikistan.

HOST. Was collected from Artemisia songarica Schrenk and A. tomentella Trautv., both from the subgenus Dracunculus [Mityaev, 2002].

\section{Macropsidius involutus Dlabola, 1963} Figs 10-12, 99-128

Macropsidius serratus Logvinenko, 1965 [Tishechkin, 2006] Macropsidius variabilis Mitjaev, 1971 [Tishechkin, 2006]

Macropsidius arenosus Mitjaev, 1971, syn. n.

Macropsidius ersinicus Vilbaste, 1980, syn. $\mathbf{n}$.

Coloration typical. Penis with wide lateral carinae more or less dentified in distal part (Figs 99-128). The shape and length of the apical part of penis varies greatly. Also, it must be taken into account, that in M. involutus as well as in many other representatives of the genus back view of penis depends greatly on its position: even slight deviation up or down results in the considerable change of apex length in the drawings (Figs 120-121). Tips of pygofer processes acute or rounded, occasionally both variants can be found in the same specimen (Figs 10-12).

Identifications of $M$. involutus and $M$. ersinicus are based on original descriptions, identification of $M$. serratus - on original description and investigation of specimens collected on Kerchenskiy Peninsula (Crimea) ca. $20 \mathrm{~km}$ from the type locality. Identifications of $M$. variabilis and $M$. arenosus are based on investigation of specimens from Kazakhstan identified by Prof. I.D. Mityaev. Illustrated redescription of $M$. involutus with data on acoustic signals is given in Tishechkin [2006].

According to the original description, M. arenosus from the deserts of the Southern Kazakhstan (Southern shore of Balkhash Lake between Karatal and Lepsy Rivers, and Alakul' Lake Depression) differs from $M$. involutus by shorter and uniformly tapered apical part of penis without spatulate ex-

Рис. 68-98. Цикадки рода Macropsidius: 68-70, 73-76, 78-79, 84, 87-90, 93-95 — пенис сзади; 71-72, 77, 82-83, 86, 91-92, 96-98 то же, сбоку; 80-81 — то же, в разных ракурсах со стороны вершины; 85 - то же, со стороны вершины и несколько сбоку. 68-72 - $M$. niger bajanagti; 73-77 - M. niger niger; 78-83 - M. chazarianus; 84-86- M. compactus; 87-92 - M. maculatus; 93-98-M. desertus. 

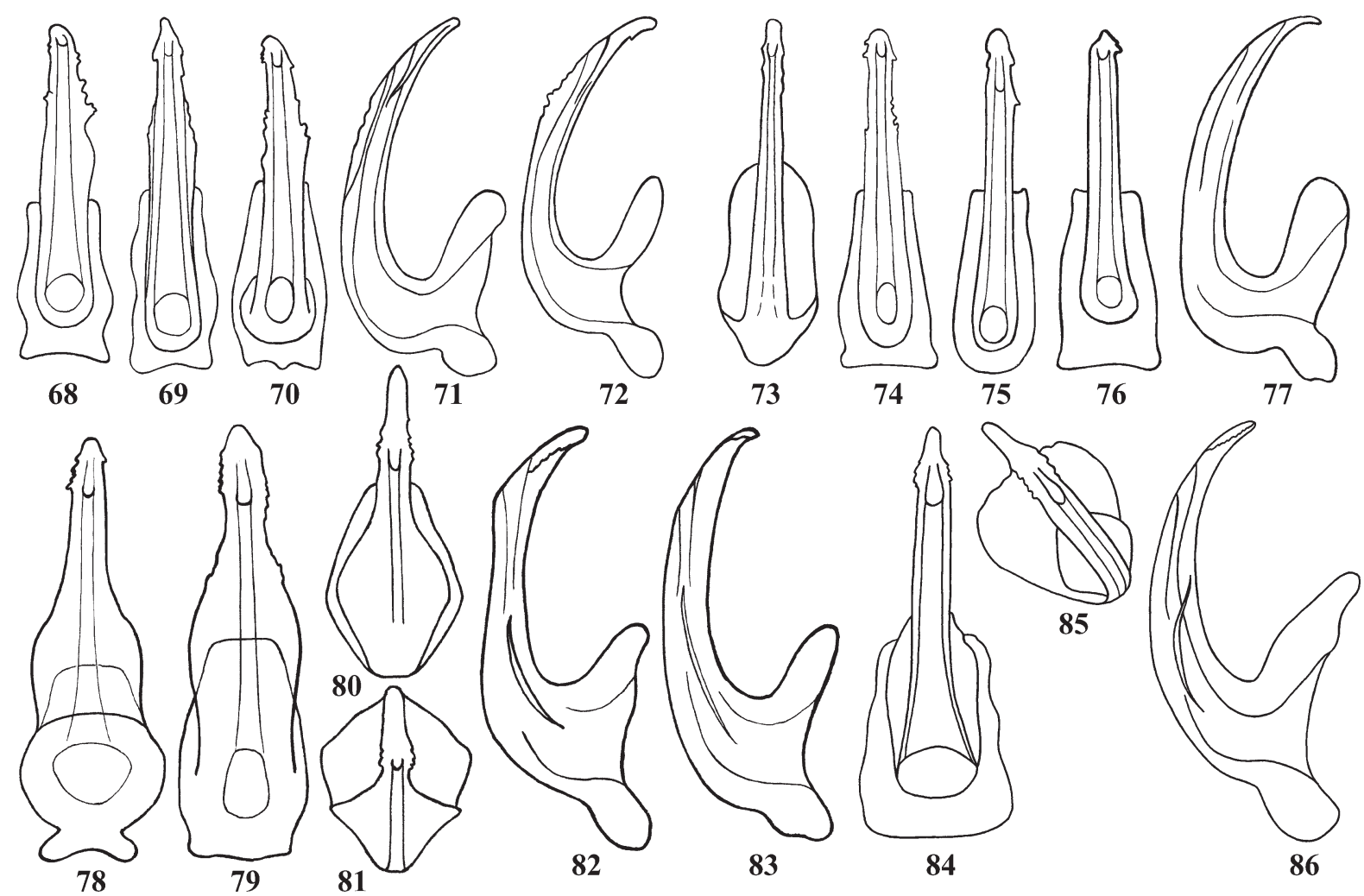

73
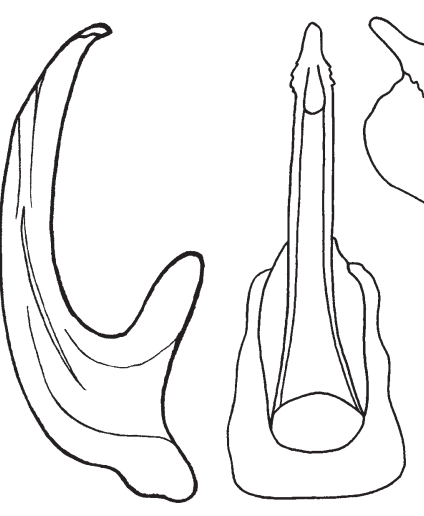

84
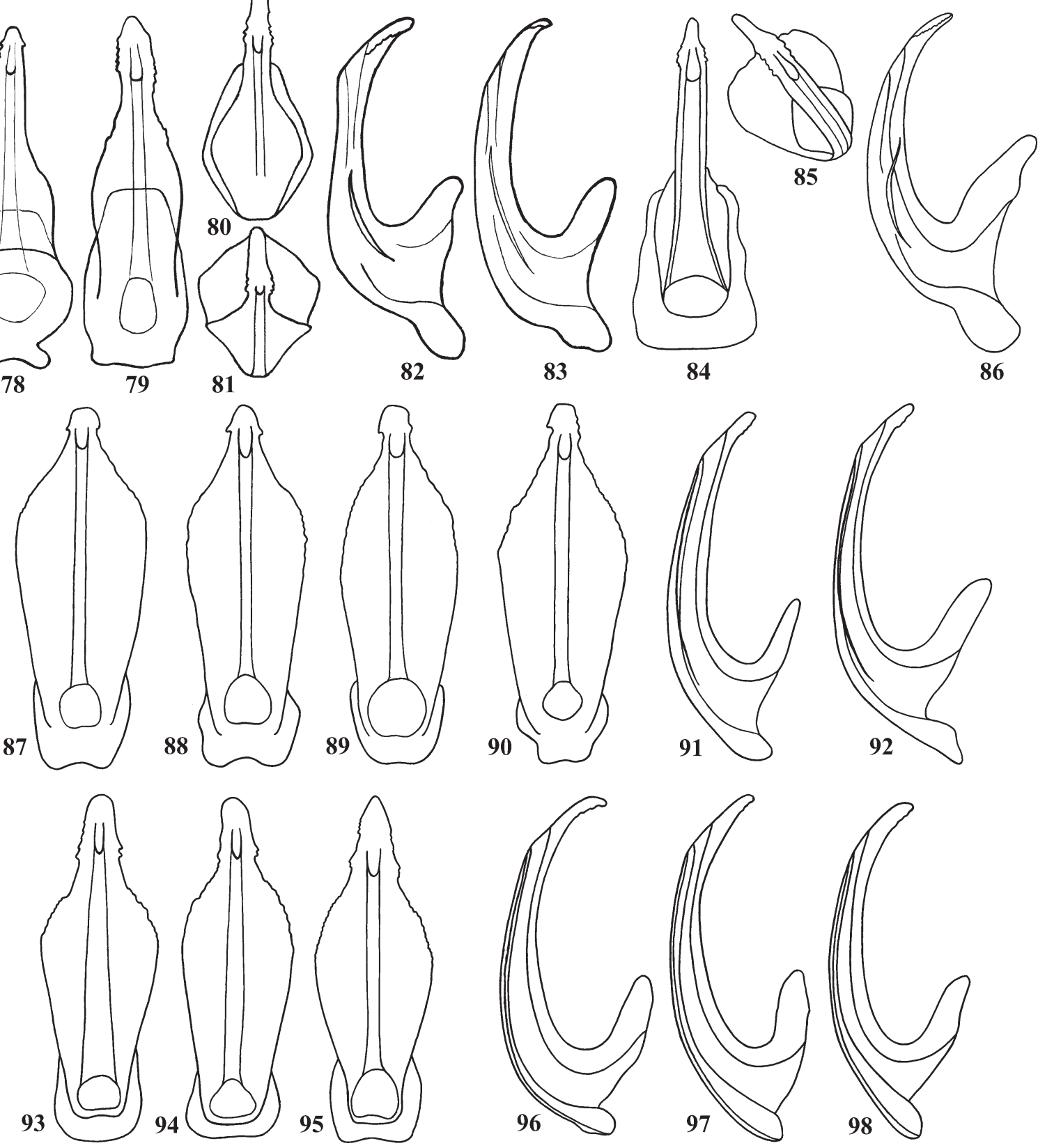

Figs 68-98. Leafhoppers of the genus Macropsidius: 68-70, 73-76, 78-79, 84, 87-90, and 93-95 — penis, back view; 71-72, 77, 8283, 86, 91-92, and 96-98 - same, side view; 80-81 - same, apical views from different angles; 85 - same, apical and somewhat lateral view. 68-72 - M. niger bajanagti; 73-77-M. niger niger; 78-83 - M. chazarianus; 84-86-M. compactus; 87-92 - M. maculatus; 93-98 - M. desertus. 
pansion. However, investigation of many specimens of $M$. involutus from Kerchenskiy Peninsula (Figs 100-104) revealed several males with almost reduced spatulate expansion and hardly distinguishable denticle only on one side of the apex of penis (Figs 103-104). On the other hand, in males from the Southern Kazakhstan (Karatal River flood-plain North of Ush-Tobe) identified as M. arenosus by Prof. I.D. Mityaev (Figs 105-108) the shape of apical part of penis varies greatly, moreover, among them there are specimens indistinguishable from M. involutus from Crimea (Fig. 105). In the populations from other regions variability of this character is no less great. All these facts give good reason to establish the synonymy of $M$. arenosus under $M$. involutus.

$M$. ersinicus described based on single male from Southern Tyva, South Siberia (environs of Erzin Village near the boundary of Mongolia) differs from the typical M. involutus

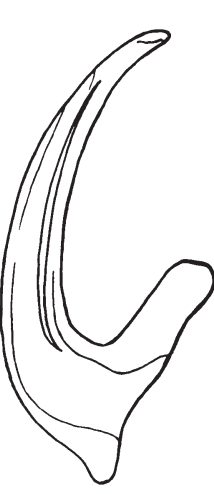

99

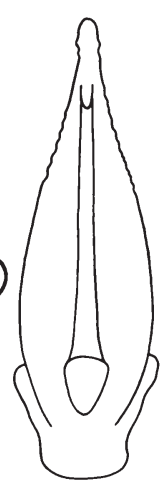

100

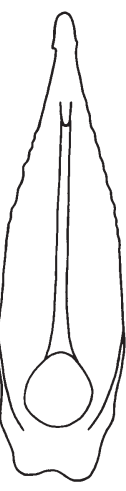

101

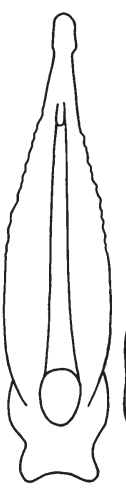

102

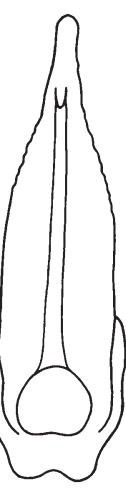

103

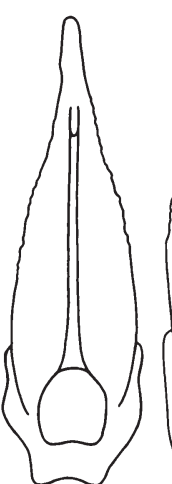

104

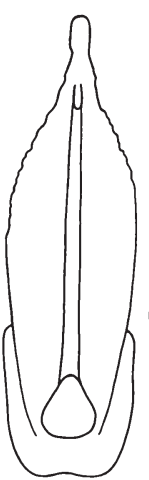

105

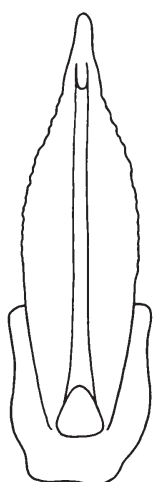

106

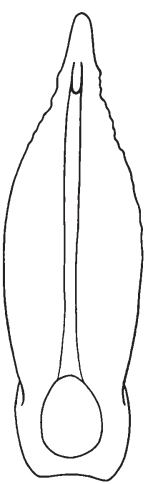

107

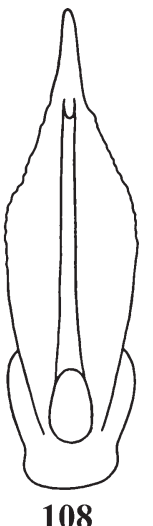

108

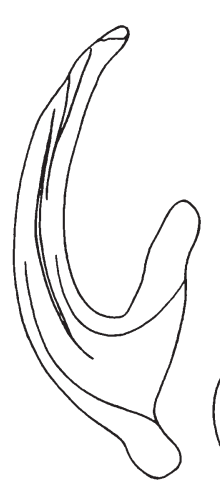

109

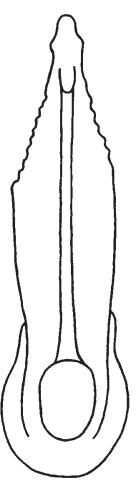

110

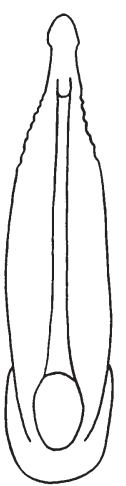

111

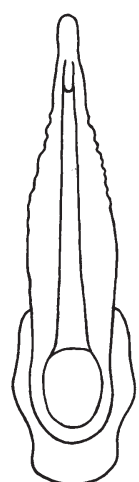

112

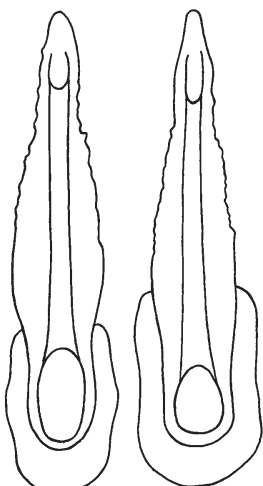

113

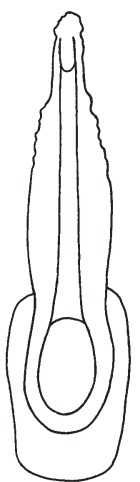

115

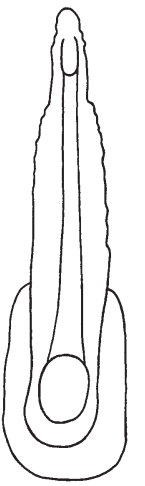

116

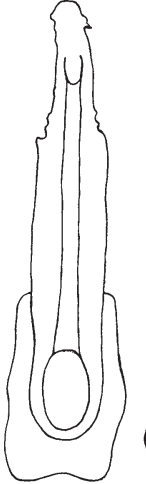

117
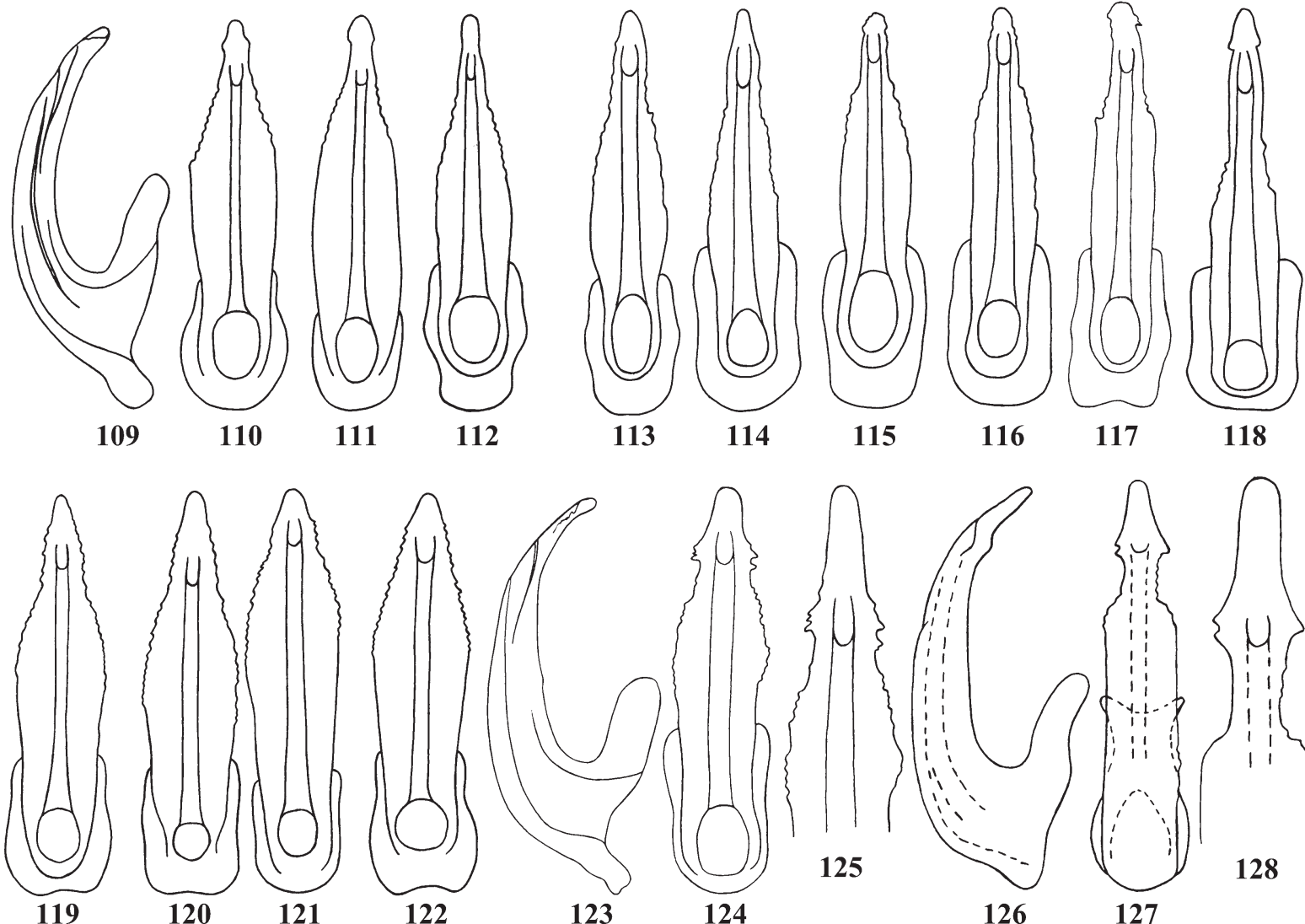

123
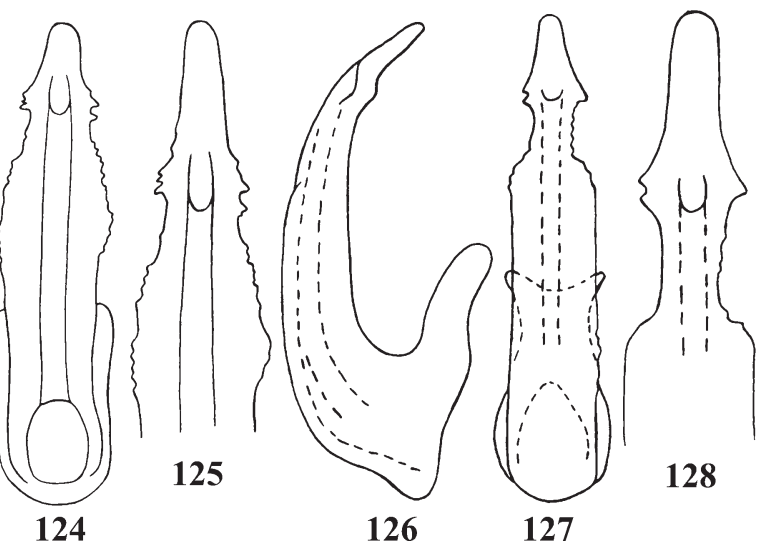

Figs 99-128. Macropsidius involutus: 99, 109, 123, and 126 - penis, side view; 100-108, 110-122, 124, and 127 — same, back view; 125 and 128 - same, apical part. 99-104 - males from Crimea, 105-108 - males from the deserts South of Balkhash Lake (M. arenosus Mitjaev det.), 109-112 - males from several localities in Central and Southern Kazakhstan, 113-118 — males from Southern Turkmenistan, 119-125 - males from Mongolia (120-121 — penis of the same specimen, views from different angles), 126-128 - M. ersinicus, holotype (after Vilbaste, 1980)

Рис. 99-128. Macropsidius involutus: 99, 109, 123, 126 - пенис сбоку; 100-108, 110-122, 124, 127 - то же, сзади; 125 и 128 — то же, вершинная часть. 99-104 - самцы из Крыма, 105-108 - самцы из пустынь южного Прибалхашья (M. arenosus Mitjaev det.), 109-112 - самцы из нескольких точек в Центральном и Южном Казахстане, 113-118 - самцы из южного Туркменистана, 119-125 — самцы из Монголии (120-121 — пенис одного экземпляра в разных ракурсах), 126-128 — M. ersinicus, голотип (по Vilbaste, 1980). 
by narrow, parallel-sided and stronger dentified lateral carinae of penis (Figs 126-128). Among many Macropsidius specimens from Mongolia collected by Prof. A.F. Emelyanov I have found only one male with similar penis shape (South-Gobian Aimag, Navtgar-Ula Mtn. 35 km NW from Yamag-Ula Mtn., 9.VIII.1974, Figs 123-125). Very occasionally similar specimens are also found in Southern Turk- menistan (Western Kopet-Dag Mtn. Range, Figs 117-118), but there is no clear-cut distinction between them and the specimens from Kazakhstan (Figs 110-112 and 113-118). Since such males are most rare in occurrence and are always found as single specimens, apparently they are not separate biological species, but merely an anomalous form of M. involutus.

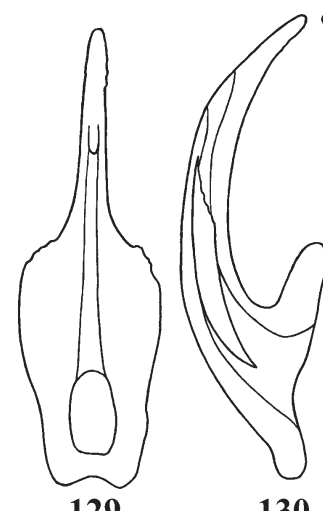

129

130

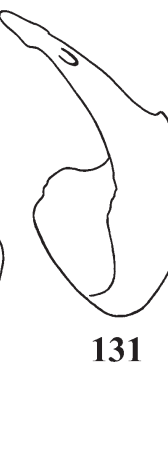

131

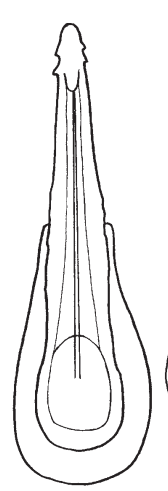

138

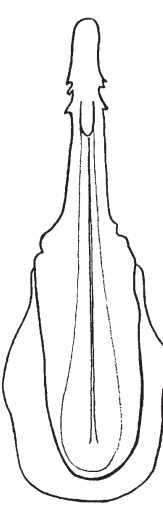

139

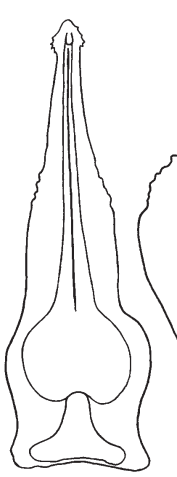

132

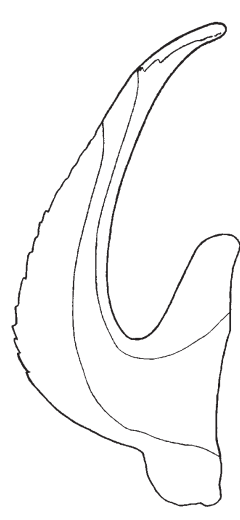

140

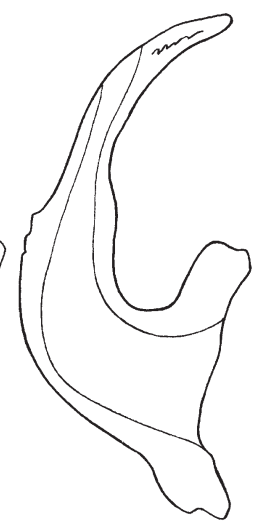

141

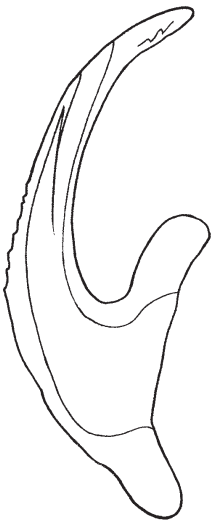

142

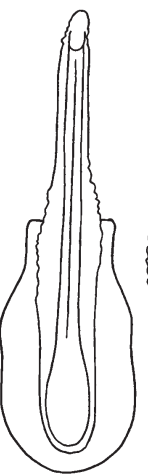

136

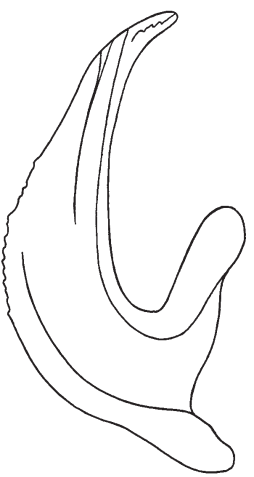

137
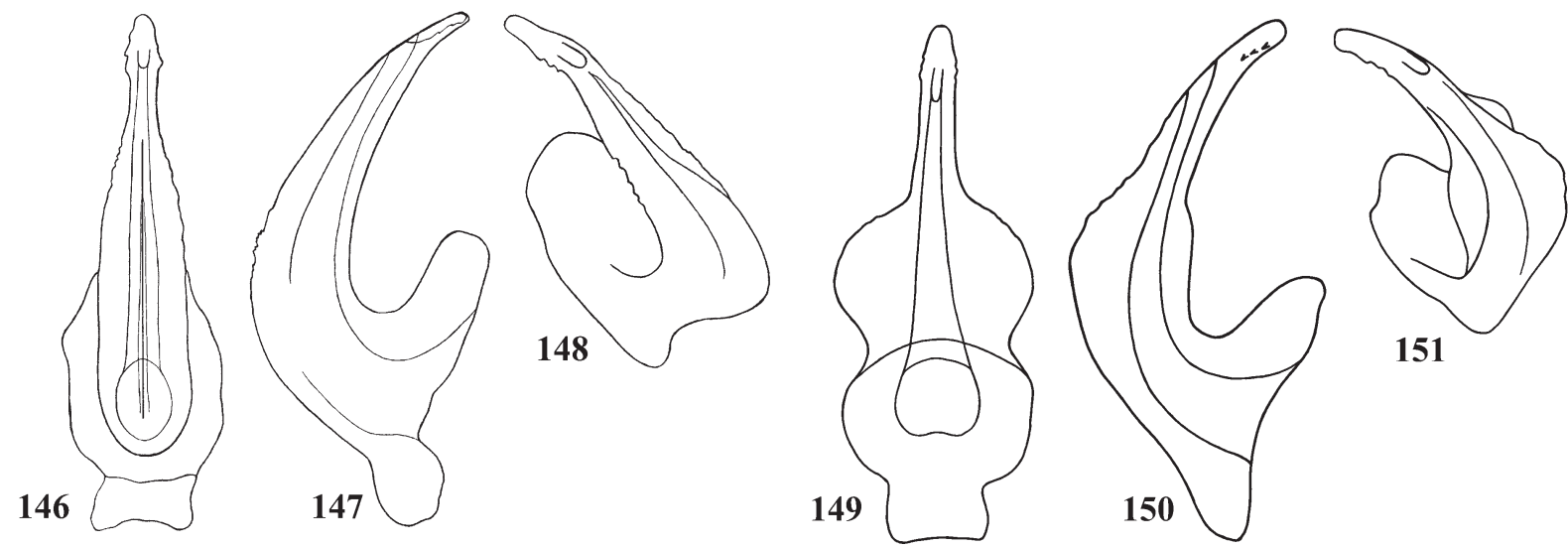

Figs 129-151. Leafhoppers of the genus Macropsidius: 129, 132, 136, 138-139, 146, and 149 - penis, back view; 130, 133, 137, 140 142, 147, and 150 - same, side view; 131, 143-144, 148, and 151 - same, apical and somewhat lateral view; 135 - same, frontal and somewhat lateral view; 134 and 145 - face. 129-131 - M. kalcanus; 132-137 - M. araxes; $138-145-$ M. valiturus; 146-148 - M. kajkanus; 149-151 - M. bogutensis.

Рис. 129-151. Цикадки рода Macropsidius: 129, 132, 136, 138-139, 146, 149 - пенис сзади; 130, 133, 137, 140-142, 147, 150 то же, сбоку; 131, 143-144, 148, 151 — то же, со стороны вершины и несколько сбоку; 135 — то же, спереди-сбоку; 134,145 — лицо. 129-131 - M. kalcanus; 132-137 - M. araxes; 138-145 - M. valiturus; 146-148 - M. kajkanus; 149-151 - M. bogutensis. 
DISTRIBUTION. Southern regions of Ukraine and European Russia (mainly saline lands on the Black Sea Coast and in Lower Volga Region), almost the whole territory of Kazakhstan; very rare and local in Central Asia.

HOST. Wormwood species from the subgenus Seriphidium.

\section{Macropsidius kalcanus Mitjaev, 1990} Figs 129-131

Pale green or yellowish green, black pattern on face, proand mesonotum usually partially or entirely absent, only occasionally well developed. Forewings always transparent, with light veins. Penis in basal part with wide lateral carinae abruptly tapered in the middle of a shaft (Figs 129-131). Apical part of penis very long and narrow.

Identification of species is based on investigation of paratypes and specimens from Southern Kazakhstan identified by Prof. I.D. Mityaev.

DISTRIBUTION. Was collected in the Great and Minor Barsuki Deserts North of Aral Sea, in the sand deserts of Middle Ili River Valley (Kazakhstan) and in Bukhara Area (Uzbekistan). Apparently, the range includes sand deserts of Kazakhstan and Western Central Asia.

HOST. Type series was collected from Artemisia sp. [Mityaev, 1990]. Later was recorded from A. santolinifolia [Mityaev, 2002].

\section{Macropsidius araxes Dlabola, 1961} Figs 132-137

Coloration typical. Penis with rather narrow lateral carinae and single ventral one widest in basal two thirds of a shaft (Figs 132-133, 135-137). Apical part with groups of denticles on both sides.

Illustrated redescription based on investigation of holotype is given in Tishechkin [2011].

DISTRIBUTION. I have investigated the male from Arax River Valley (holotype, Figs 132-135) and a series of specimens from Dagestan (environs of Gubden Town, Figs 136137). Apparently, the range includes arid regions of Eastern Caucasus and Transcaucasia.

HOST. Unknown.

\section{Macropsidius valiturus Dlabola, 1963} Figs 4-6, 138-145

Macropsidius demavendinus Dlabola, 1974 [Tishechkin, 2011] Macropsidius tricostatus Logvinenko, 1981 [Tishechkin, 2011]

Coloration typical (Figs 4-6). Penis with two lateral and one ventral carinae (Figs 138-144). As a rule all carinae are widest in basal half of a shaft. Apical part with groups of denticles on both sides. Closely related to $M$. araxes and M. kajkanus. Differs from the former species by less developed carinae of penis and the shape of spots on face (Figs 134 and 145), and from the latter one by almost parallel-sided distal half of penis shaft in lateral view (Figs 140-142 and 147).

Identification of $M$. valiturus is based on investigation of type series, identification of $M$. demavendinus - on investigation of the drawings and photographs of paratype genitalia and of the specimens from several localities in Iran. Identification of $M$. tricostatus is based on original description. Illustrated redescription is given in Tishechkin [2011].

DISTRIBUTION. Georgia, Azerbaidzhan (Mugansk Steppe and Nakhichevan'), Iran.

HOST. In Nakhichevan' was found on dry slopes with Artemisia sp. and Achillea sp. [Logvinenko, 1981].

\section{Macropsidius kajkanus Mitjaev, 1990 \\ Figs 146-148}

Coloration typical. Penis with two lateral and one ventral carinae (Figs 146-148). All carinae comparatively narrow, gradually tapered apically. Very similar to $M$. valiturus and differs from it only by somewhat wider penis uniformly tapered apically in lateral view. In addition, M. valiturus occurs in Transcaucasia and Iran, whereas M. kajkanus was found only in South-Eastern Kazakhstan.

Identification of species is based on investigation of paratypes. Drawings of genitalia in addition to original description are given in Tishechkin [2011].

DISTRIBUTION. Kaykan Mtn. Range (South-Eastern Kazakhstan, North-Eastern part of Dzhungarskiy Alatau Mtn. Range).

HOST. Artemisia juncea Kar. et Kir. from the subgenus Seriphidium [Mityaev, 2002].

\section{Macropsidius bogutensis Mitjaev, 1990 \\ Figs 149-151}

Coloration typical. Penis with two lateral and one ventral carinae (Figs 149-151). The formers are strongly expanded in basal half of the shaft and almost reduced in distal half so that penis looks pyriform in back view.

Identification of species is based on investigation of paratypes and specimens from Southern Kazakhstan identified by Prof. I.D. Mityaev.

DISTRIBUTION. Southern Kazakhstan, arid mountains of Middle Ili River Valley: Boguty Mts., Malaysary Mtn. Ridge.

HOST. Was collected from Artemisia juncea and A. terrae-albae Krasch., both from the subgenus Seriphidium [Mityaev, 2002].

\section{Macropsidius vallaris Dlabola, 1963} Figs 7-9, 24-26, 152-158

Macropsidius montanus Lukjanova, 1992 [Tishechkin, 2007]

Coloration typical, occasionally more contrasting than in other species (Figs 7-9, 24-26). Penis with two lateral and two ventral carinae (Figs 152-158). The formers are strongly expanded in basal half of the shaft so that penis looks pyriform in back view.

Identifications of M. vallaris and M. montanus are based on original descriptions and on investigation of specimens from many localities in Central Asia. Illustrated redescription is given in Tishechkin [2007].

DISTRIBUTION. Turkmenistan (Kugitang Mtn. Range), East of Uzbekistan, Tajikistan (Zeravshan River Valley, Vakhsh and Transalay Mtn. Ranges), South-Western border of Ferghana Valley (environs of Sokh Village $70 \mathrm{~km}$ South of Kokand).

HOST. Artemisia sp.

\section{Macropsidius mitjaevi Tishetshkin, 2011} Figs 159-165

Coloration typical. As in M. vallaris, penis with two lateral and two ventral carinae, but the formers are much more narrow and the latters are set wider apart and directed laterally so that penis looks narrow, almost parallel-sided in back view (Figs 159-165).

DISTRIBUTION. Was described from the foothills on the Southern and South-Eastern boundaries of Kyzylkum Desert and in their central part (Tamdytau Mts.). Later was found in materials from Akmolinsk Area (Kazakhstan) and Mongolia.

HOST. Artemisia from the subgenus Seriphidium. 
22. Macropsidius dispar (Fieber, 1868)

Figs 166-169

Pediopsis dispar Flor, 1868

Macropsidius hispanus Dlabola, 1963 [Dlabola, 1975]

Coloration typical, but central part of pronotum sometimes is strongly darkened, especially in males. Penis in back view wide in basal part, gradually tapered apically, without longitudinal carinae (Figs 166-169).

Identification of species is based on description in Ribaut [1952] and investigation of specimens from Spain.

M. parvus Ribaut, 1959 described based on the single male from Southern France (Alpes-Maritimes) is very similar

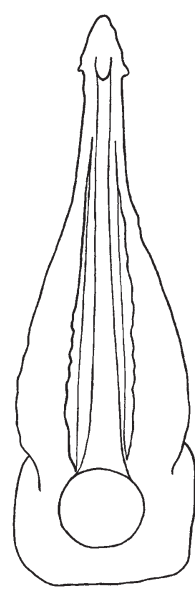

152
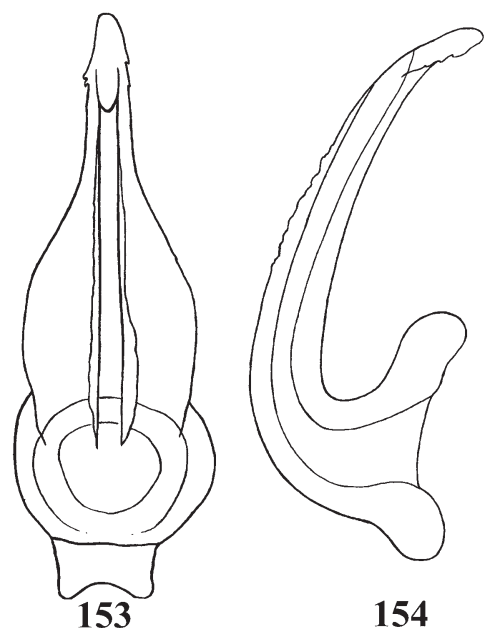

154

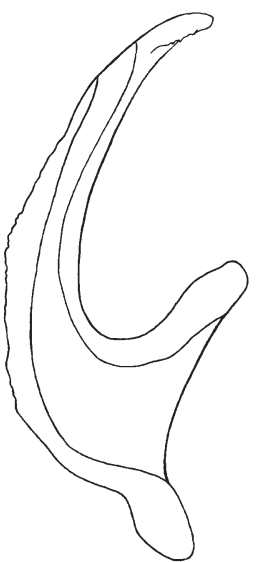

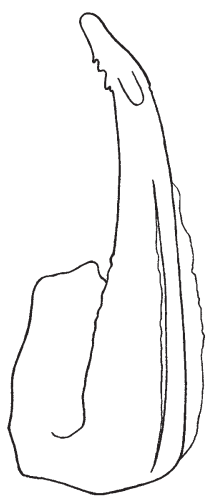

156

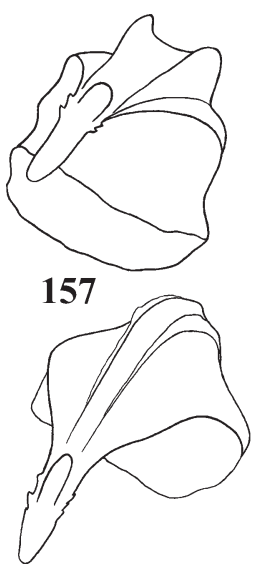

158

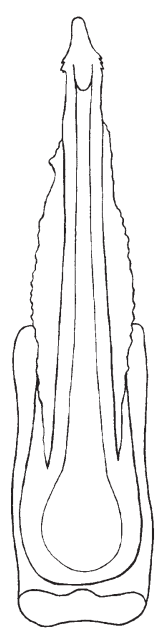

159
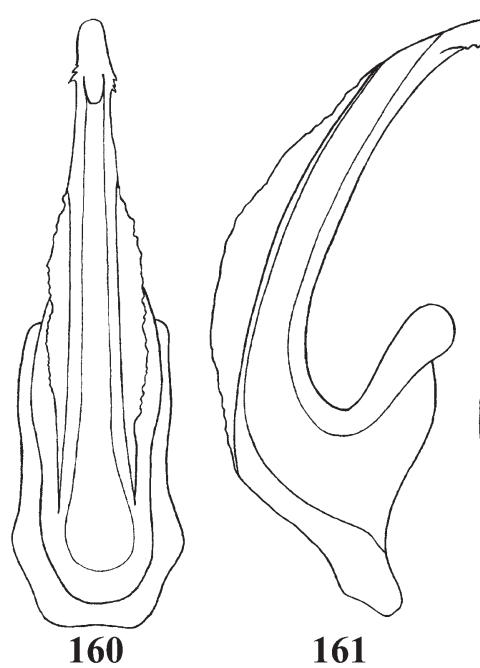

161
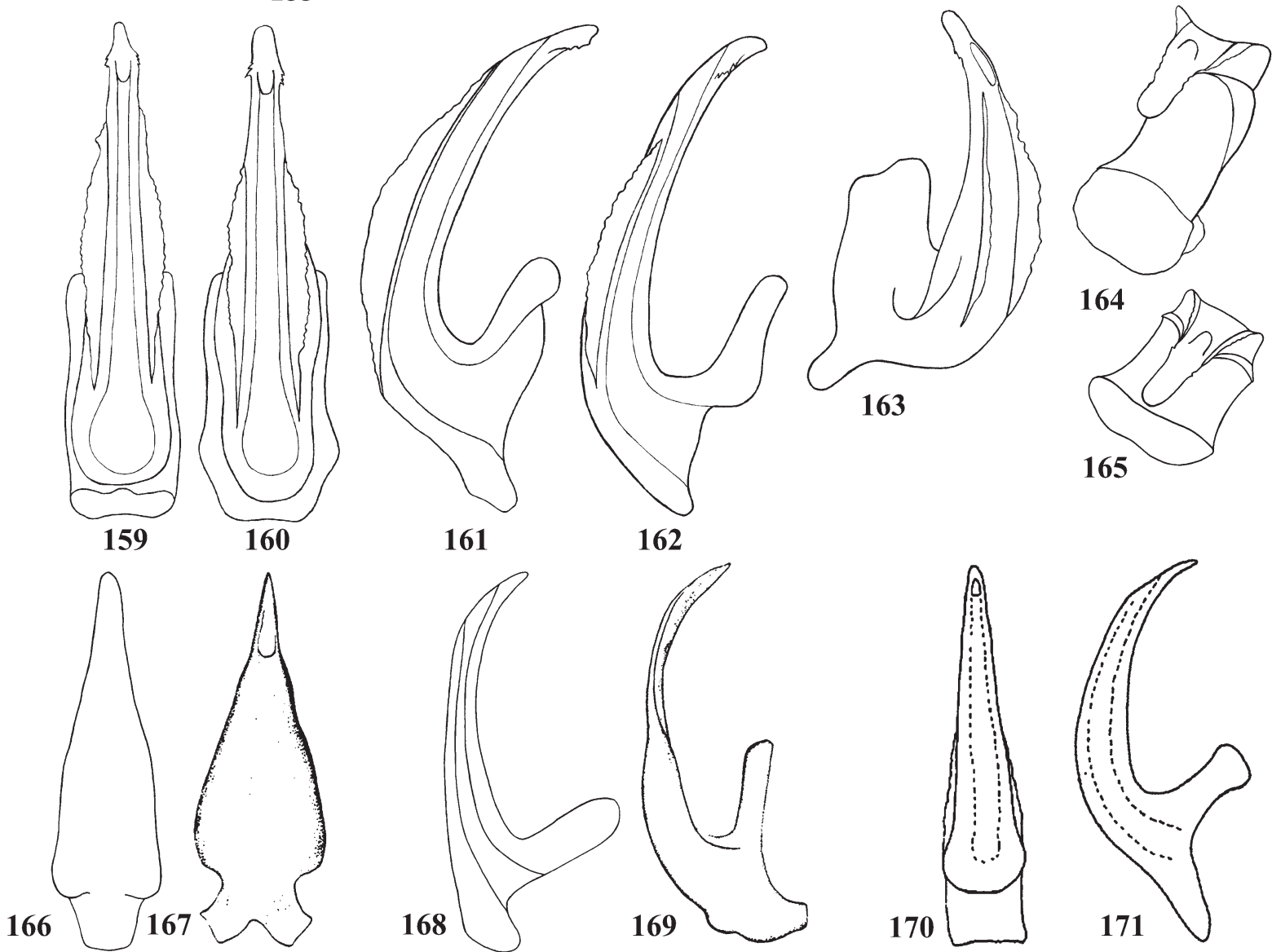

165

162
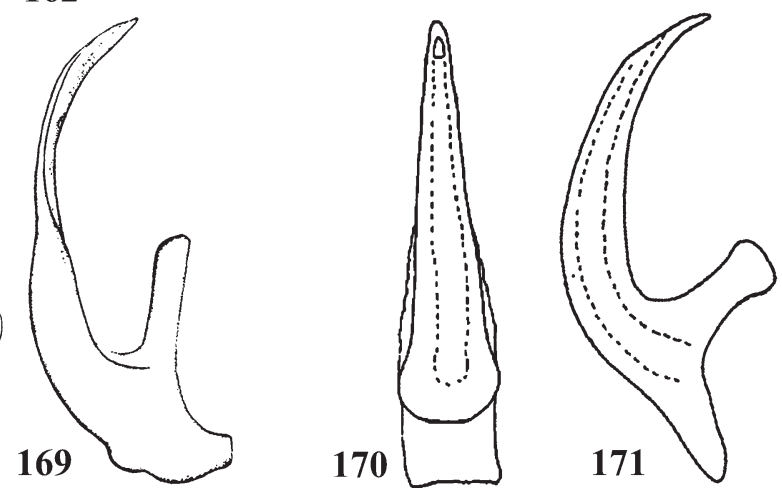

Figs 152-171. Leafhoppers of the genus Macropsidius: 152-153, 159-160, 166-167, and 170 - penis, back view; 154-155, 161-162, 168-169, and 171 — same, side view; 156 and 163 — same, back and somewhat lateral view; 157-158 and 164-165 — same, apical and somewhat lateral view; 152-158 - M. vallaris; 159-165 - M. mitjaevi; 166-169 - M. dispar (167 and 169 — after Dlabola, 1975); 170171 - M. parvus (after Giustina, 1989).

Рис. 152-171. Цикадки рода Macropsidius: 152-153, 159-160, 166-167, 170 - пенис сзади; 154-155, 161-162, 168-169, 171 то же, сбоку; 156, 163 - то же, сзади-сбоку, 157-158, 164-165 - то же, со стороны вершины и несколько сбоку; 152-158 - M. vallaris; 159-165 — M. mitjaevi; 166-169 - M. dispar (167, 169 — по Dlabola, 1975); 170-171 — M. parvus (по Giustina, 1989). 
to $M$. dispar and differs from it only by narrower penis [Ribaut, 1959]. According to Giustina [1989], genitalia preparation is absent in Ribaut collection, the species was not found later on, so its existence "seems hypothetical". Judging from the illustrations in original description (Figs 170-171), this taxon was described based on the specimen of $M$. dispar with extremely narrow penis. However, investigation of the variability of the latter species is desirable for formal establishing the synonymy.

DISTRIBUTION. Spain, Southern France. Records from Russia and adjacent territories [e.g. in Logvinenko, 1981] apparently are in error.

HOST. Artemisia campestris [Ribaut, 1952].

Since this species was not found in Russia, it is not included in the key to species given below.

KEY TO SPECIES OF MACROPSIDIUS OF RUSSIA AND ADJACENT TERRITORIES.

1 Background coloration black or infumose (Figs 29-33). M. niger.

- Background coloration light, very rarely in certain specimens central part of pronotum or forewings more or less darkened (Figs 20-28). .

2 Penis with two apical processes (Figs 34-36, 40-41). 3

- Penis without apical processes, usually with one or several denticles on each side of the gonopore. .................. 4

3 Penis with rather short and slender apical part (Figs 34 36) and narrow shaft in lateral view (Figs 37-39). Body length in male $3.5-4.1 \mathrm{~mm}$, in female $-3.8-4.5 \mathrm{~mm}$.

M. duuschulus.

- Penis with larger apical part (Figs 40-41) and wider shaft in lateral view (Figs 42-43). Body length in male 3.1-3.5 $\mathrm{mm}$, in female - 3.4-4.1 mm................ M. arenicola.

4 Penis with basal expansion densely covered with minute denticles. (Figs 47-48).......................... M. ilandagicus.

- Penis without basal expansion covered with denticles. 5

5 Penis without longitudinal carinae (Figs 44-46, 62-67); sometimes in M. majusculus with very narrow carinae in the middle part of the shaft (Figs 58-61). ................. 6

- Penis with one or several longitudinal carinae at least in basal part of the shaft.

6 Penis with widely rounded apex in back view (Fig. 44). Ukraine, Southern half of European Russia, Kazakhstan. M. abrotani.

- Penis with somewhat extended and flattened apical part (Figs 58, 62, 64-66).

7 Apical part of penis with a group of denticles on each side (Figs 64-66). Western Kopet-Dag Mtn. Range (Turkemenistan). M. kopetdagicus.

- Apical part of penis with one or rarely two denticles on each side (Figs 58, 61-63). Southern Kazakhstan, Kyrgyzstan. .............................................. M. majusculus.

8 Penis with very wide ventral carina throughout all its length (Figs 50, 52-57). ........................................... 9

- Penis without ventral carina or with one or two rather narrow ventral carinae. ........................................ 10

9 Penis shaft extended basally in back view, with elongated apex (Figs 49-50)................................... M. kalbensis.

- Penis shaft narrow, parallel-sided in back view, with shorter apex (Figs 51-57)........................ M. sahlbergi.

10 Penis without ventral carinae (Figs 78-131). .......... 11

- Penis with one or two ventral carinae (Figs 132-133, 135144, 146-165)

11 Lateral carinae developed only in the basal part of the shaft, short and narrow, only slightly, if at all, wider than the shaft (Figs 84-86).

M. compactus.
- Lateral carinae much wider than the shaft at least in the widest point, sometimes developed throughout all its length (Figs 78-83, 87-131).

12

12 Lateral carinae expanded in basal half of the shaft and almost reduced in distal half so that penis looks pyriform in back view (Figs 78-79, 129)................................ 13

- Lateral carinae developed throughout almost all the shaft, tapered towards its apex (Figs 87-128). ................... 14

13 Lateral carinae more or less gradually tapered towards apex, apical part comparatively wide (Figs 78-83).......

M. chazarianus.

- Lateral carinae abruptly tapered at the middle of a shaft, apical part of penis very long and narrow (Figs 129-131). M. kalcanus.

14 Lateral carinae arcuate or uneven, slightly divergent or parallel in basal part, typically with numerous small denticles in distal part (Figs 99-116, 119-122), very rarely with larger irregular acute denticles (Figs 117-118, 124-125, 127-128). Penis comparatively narrow in back view. ....................................................... involutus.

- Lateral carinae almost straight and strongly divergent in basal part. Penis broader in back view (Figs 87-98). 15

15 Apical part of penis short, as a rule with a single denticle on each side (Figs 87-90). .................... M. maculatus.

- Apical part of penis elongated, as a rule with several denticles on each side (Figs 93-95). ......... M. desertus.

16 Penis with one ventral carina (Figs 132-133, 135-144, 146-151). ....................................................... 17

- Penis with two ventral carinae (Figs 152-165). ...... 20

17 Lateral carinae narrow, only slightly, if at all, expanded in the middle part (Figs 132-133, 135-144, 146-148). ....... 18

- Lateral carinae strongly expanded in basal part so that penis looks pyriform in back view (Figs 149-151).......

M. bogutensis.

18 Black spots in the central part of face strongly curved outwards, almost touch each other by the lower ends (Fig. 134). Apical part of penis comparatively short (Figs 132133, 136-137). M. araxes.

- Black spots in the central part of face almost straight, parallel-sided, do not touch each other by the lower ends (Fig. 145). Apical part of penis usually elongated (Figs 138-144, 146-148).

19 Penis shaft in side view as a rule somewhat unevenly tapered apically, almost parallel-sided in the distal half, its subapical part rather narrow (Figs 140-142). Transcaucasia, Iran.

M. valiturus.

- Penis shaft in side view uniformly tapered apically, its ventral edge forms fair-curve, subapical part wider (Fig. 147). Eastern Kazakhstan (Dzhungarskiy Alatau Mtn. Ridge). M. kajkanus.

20 Lateral carinae wide, strongly curved, widest in the basal half (Figs 152-153). ................................... M. vallaris.

- Lateral carinae narrow, more or less parallel-sided, widest in the middle (Figs 159-160). .................... M. mitjaevi.

ACKNOWLEDGEMENTS. I am greatly indebted to Prof. A.F. Emelyanov, Zoological Institute of the Russian Academy of Sciences, St.-Petersburg, Russia and Prof. I.D. Mityaev, Institute of Zoology, National Academy of Sciences, Almaty, Kazakhstan for the loan of the material on Macropsidius, and to Dr. V.M. Gnezdilov, Zoological Institute of the Russian Academy of Sciences and Dr. I. Malenovsky, Department of Entomology, Moravian $\mathrm{Mu}-$ seum, Brno, Czech Republic for invaluable help in investigation of type specimens from the collection of Dr. J. Dlabola. 
The study was supported by Russian Foundation for Basic Research, grant No. 13-04-00046-a.

\section{References}

Abdurakhimov K.A. 1972. [Materials on the fauna of Auchenorrhyncha (Cicadinea) of the environs of Issyk-Kul'] // Nauchnye Trudy Tashkentskogo Universiteta. No.398. P.221-232 [in Russian].

Anufriev G.A. 1978. [Leafhoppers of the Maritime Province (Homoptera, Auchenorrhyncha, Cicadellidae)] // Trudy Vsesoyuznogo Entomologicheskogo Obshchestva. Vol.60. 215 pp. [in Russian].

Dlabola J. 1963. A revision of the leafhopper genus Macropsidius Rib. (Hom., Auchenorrhyncha) // Acta Soc. Entomol. Cehosloveniae. T.60. No.1-2. P.114-124.

Dlabola J. 1975. Neue mediterrane Zikadenarten der Gattungen Hysteropterum Amyot \& Serville, 1843, Macropsidius Ribaut, 1952, und Chlorita Fieber, 1872 (Homoptera, Auchenorrhyncha) // Beaufortia. Vol.23. No.299. P.75-83.

Emelyanov A.F. 1964. [Suborder Cicadinea (Auchenorrhyncha)] // Opredelitel' nasekomyh evropeyskoy chasti SSSR. Vol.1. Moscow-Leningrad: "Nauka" Publ. P.337-437 [in Russian].

Emeljanov A.F. 1972. [New Auchenorrhyncha from the Mongolian People's Republic] // Nasekomye Mongolii. No.1. P.199-260.

Giustina W. della. 1989. Homoptères Cicadellidae. Faune de France. Vol.73. No.3. P.1-350.

Hamilton K.G.A. 1980. Contribution to the study of the world Macropsini (Rhynchota: Homoptera: Cicadellidae) // Can. Entomol. Vol.112. No.9. P.875-932.

Hamilton K.G.A. 1983. Revision of the Macropsini and Neopsini of the New World (Rhynchota: Homoptera: Cicadellidae), with notes on intersex morphology // Mem. Entomol. Soc. Canada. No.123. P.1-223.

Logvinenko V.N. 1981. [Leafhoppers of the genus Macropsidius Rib. (Homoptera, Auchenorrhyncha, Cicadellidae) on the Caucasus] // Vestnik Zoologii. No.6. P.37-43 [in Russian].

Lukjanova O.N. 1992. [A new species of the genus Macropsidius Rib. (Homoptera, Auchenorrhyncha, Cicadellidae) from Tajikistan] // Doklady Akademii Nauk Respubliki Tajikistan. Vol.35. No.3-4. P. 221-223 [in Russian].
Mityaev I.D. 1967. [New and little-known species of Cicadinea (Homoptera, Auchenorrhyncha) from Eastern Kazakhstan] // Entomologicheskoe Obozrenie. Vol.46. No.3. P.712-723 [in Russian].

Mityaev I.D. 1971. [Cicadinea of Kazakhstan. Keys for identification of species]. Alma-Ata: "Nauka" Publ. 211 pp. [in Russian].

Mityaev I.D. 1973. [A description of some leafhoppers of the genus Macropsidius Rib., 1952 (Homoptera, Cicadellidae) from Kazakhstan]//Entomologicheskoe Obozrenie. Vol.52. No.2.P.347351 [in Russian].

Mityaev I.D. 1990. [New Auchenorrhyncha from mountain landscapes of Kazakhstan] // Trudy Instituta Zoologii Akademii Nauk Kazakhskoy SSR. Vol.45. P.5-20 [in Russian].

Mityaev I.D. 2002. [Fauna, ecology and zoogeography of Auchenorrhyncha of Kazakhstan] // Tethys Entomol. Research. Vol.5. P.1-168 [in Russian].

Ribaut H. 1952. Homoptères Auchénorhynques. II (Jassidae) // Faune de France. Vol.57. P.1- 474.

Ribaut H. 1959. Homoptères nouveaux pour la France // Bulletin de la Société d' Histoire Naturelle de Toulouse. Vol.94. P.393-399.

Tishechkin D.Yu. 2003. Vibrational communication in leafhoppers from Ulopides subfamilies group (Homoptera: Cicadellidae) and Membracidae with notes on classification of higher taxa // Russian Entomol. J. Vol.12. No.1. P.11-58.

Tishechkin D.Yu. 2006. [Leafhoppers of the genus Macropsidius (Homoptera, Cicadellidae, Macropsinae) of European Russia] // Zoologicheskii Zhurnal. Vol.85. No.4. P.470-478 [in Russian]. English translation: Entomological Review. 2006. Vol.86. No.2. P.230-239.

Tishechkin D.Yu. 2007. [New data on systematics of leafhoppers of the genus Macropsidius (Homoptera, Cicadellidae, Macropsinae)] // Zoologicheskii Zhurnal. Vol.86. No.2. P.204-210 [in Russian]. English translation: Entomological Review. 2007. Vol.87. No.2. P.174-180.

Tishechkin D.Yu. 2011. [On the taxonomy of the leafhopper genus Macropsidius (Homoptera, Cicadellidae)] // Zoologicheskii Zhurnal. Vol.90. No.12. P.1438-1447 [in Russian]. English translation: Entomological Review. 2012. Vol.92. No.1. P.83-92.

Vilbaste Yu.G. 1965. [On the fauna of Cicadinea of Altai Mountains]. Tartu. 144 pp. [in Russian, with German summary].

Vilbaste Yu.G. 1980. [Fauna of Cicadinea of Tuva]. Tallinn: Valgus Publ. 219 pp. [in Russian, with English summary]. 